\title{
FIELD AND LABORATORY STUDIES OF THE EARTHWORM DENDROBAENA ALPINA
}

\author{
Joanna Kostecka', Kevin R. Butt ${ }^{2}$ \\ 1 Faculty of Biology and Agriculture, University of Rzeszow, Ćwiklińskiej 2, 35-959, Rzeszów, Poland, e-mail: \\ jkosteck@ur.edu.pl \\ 2 University of Central Lancashire, School of Forensic and Applied Sciences, Preston PR1 2HE, United Kingdom, \\ e-mail: KRButt@uclan.ac.uk
}

Received: 2015.09.19

Accepted: 2015.10.06

Published: 2015.11.10

\begin{abstract}
Distribution of Dendrobaena alpina covers the mountainous region of central Europe, where it has a high dominance and frequency index. This work describes data from field studies conducted over two annual cycles in the Bieszczady National Park (BNP), Poland, in different types of beech forest. Densities of this species ranged from 47-231 $\mathrm{g} \cdot \mathrm{m}^{-2}$ with associated biomasses of $19-90 \mathrm{~g} \cdot \mathrm{m}^{-2}$. Most $(66 \%)$ were recovered from less than $0.1 \mathrm{~m}$ soil depth with a further $28 \%$ from up to $0.2 \mathrm{~m}$. Further, the animals were collected alive from Lutowiska, close to the BNP to obtain baseline data on the life history of $D$. alpina. Mature individuals were kept in isolation and cocoon production monitored on a 2 monthly basis. Immature individuals were kept until they reached maturity, when they were paired, with combined output of cocoons regularly monitored. Cocoons were collected, had their masses determined and were incubated. Hatchability was recorded, as was estimated duration of incubation and growth to maturity. Field-collected adults had a mean mass of $1.4 \mathrm{~g}$ and at $15{ }^{\circ} \mathrm{C}$, these produced an average of 1.83 cocoons $\cdot$ worm $^{-1} \cdot \mathrm{month}^{-1}$. Zero cocoons were produced by further specimens, collected as immature, grown to maturity and maintained in isolation. Recently-matured, paired D. alpina produced an average of 1.65 cocoons $\cdot$ worm $^{-1} \cdot$ month $^{-1}$. Cocoons had a mean mass of $19 \mathrm{mg}$. At $15^{\circ} \mathrm{C}$, cocoons produced by recently matured adults hatched after 80 days ( $82 \%$ viable), but after 2 months the majority of cocoons failed to hatch. Hatchling growth from an average of $18 \mathrm{mg}$ to maturity required $7-11$ months in the given substrate.
\end{abstract}

Keywords: earthworms, D. alpina, field study, laboratory culture, population dynamics.

\section{INTRODUCTION}

Dendrobaena alpina (Rosa, 1884) (Annelida/ Clitellata/ Oligochaeta/ Lumbricidae) occurs in the Alps, the Southern Carpathians and Balkans [Csuzdi et al. 2005]. It is characterised by a cylindrical body shape (length $40-120 \mathrm{~cm}$ with $65-155$ segments). The species is variable in colour, ranging from violet to bright red dorsally and rosy-tinged beige ventrally. It has an epilobic prostomium and distantly spaced chaetae. The clitellum is present across segments 28-33. In the field, it is easily recognized among other similarly coloured earthworm species by its vio- lent escape response. Previous studies in Poland within the Bieszczady National Park (BNP), SE Poland, have shown associations of D. alpina with Allolobophora carpathica (Cognetti, 1927), Allolobophora cernosvitoviana (Zicsi, 1967) and Aporrectodea rosea (Savigny, 1826). Field sampling in beech woodlands within the BNP, found D. alpina in soils with a $\mathrm{pH}$ of 3.35.0 and C:N ratios around 13:1 [Kostecka and Skoczeń 1993].

This paper combines unpublished data from field sampling over two field seasons with controlled laboratory investigations to rear of $D$. alpina. The aims were to obtain fundamental infor- 
mation on population dynamics and specific data on aspects of life history of this species.

\section{MATERIAL AND METHODS}

\section{Field sampling}

Work was conducted in four areas of Carpathian beech (Fagetum carpathicum) woodland within the BNP in the vicinity of Ustrzyki Górne in the years of 1986-1987 (unpublished data). Each of the four sites (sub-assemblies of the beech woodland) was classified according to a homogenous ground flora community cover: $1-F$. c. festucetosum drymejae; $2-F$. c. typicum; $3-F$. c. lunarietosum; $4-F$. c. allietosum. Sampling, over two field years was during the months of May to November, when access to field sites is possible. Within each site and on all occasions, 5 samples were taken. Soil blocks $0.25 \times 0.25 \times 0.2 \mathrm{~m}$ were dug out and the soil was inspected by hand sorting, with specimens from deeper layers extracted with a $0.4 \%$ formalin solution. Collected specimens were preserved in $4 \%$ formalin in the field for later identification. The relative contribution of D. alpina (Figure 1) to the total earthworm community at each site was determined. Mean densities and masses for D. alpina at the given sampling sites were also calculated. Earthworms densities between sites were compared using ANOVA with a post hoc HSD Tukey's test.

\section{Laboratory monitoring}

In June 2008, live specimens of D. alpina were collected by digging and hand-sorting of soil from beech-dominated forest soils near Lutowiska (N 49 $17.11^{\prime}$ E $\left.22^{\circ} 40.91^{\prime}\right)$ close to the BNP.
These mature and immature animals $(n=36)$ were transported to the laboratory in native soils for examination of life history traits. To obtain maximum data, the animals were treated as described by Butt and Grigoropoulou [2010]. Initially, each one was examined, identified as closely as possibly, had stage of development and mass recorded. Each was then individually housed in a $0.4 \mathrm{dm}^{3}$ plastic container with a small proportion of native soil supplemented with Kettering loam and surface fed with dried and re-wetted horse manure [Lowe and Butt 2005]. These animals were maintained at $15^{\circ} \mathrm{C}$ in temperature-controlled chambers and initially monitored on a monthly basis. Masses were recorded and, if clitellate at time of collection, the soil in which the earthworm was kept was wet-sieved for cocoons (sieves of 4.0, 2.8 and $2.0 \mathrm{~mm}$ ). Thereafter, fresh Kettering loam and food was provisioned. Immature animals were maintained in isolation until maturity was reached and then for 2 months beyond this. After maturation the soil in which the animals were kept was also wet-sieved to check for any cocoon production from unmated individuals. After this, D. alpina that had matured in the laboratory were put together $(\mathrm{n}=9$ pairs $)$ in $0.4 \mathrm{dm}^{3}$ containers and sampled monthly for cocoons over a period of 15 months as previously described.

Collected cocoons were placed on moistened filter papers within $9 \mathrm{~cm}$ diameter Petri dishes at $15{ }^{\circ} \mathrm{C}$, after cocoon masses (blotted dry) were recorded. Cocoons were monitored on a regular basis and date of hatching success, the number of hatchlings emerging and hatchling masses were recorded. The length of incubation was calculated as time required to hatch after collection plus half of the elapsed time since previous cocoon collection. Selected hatchlings were
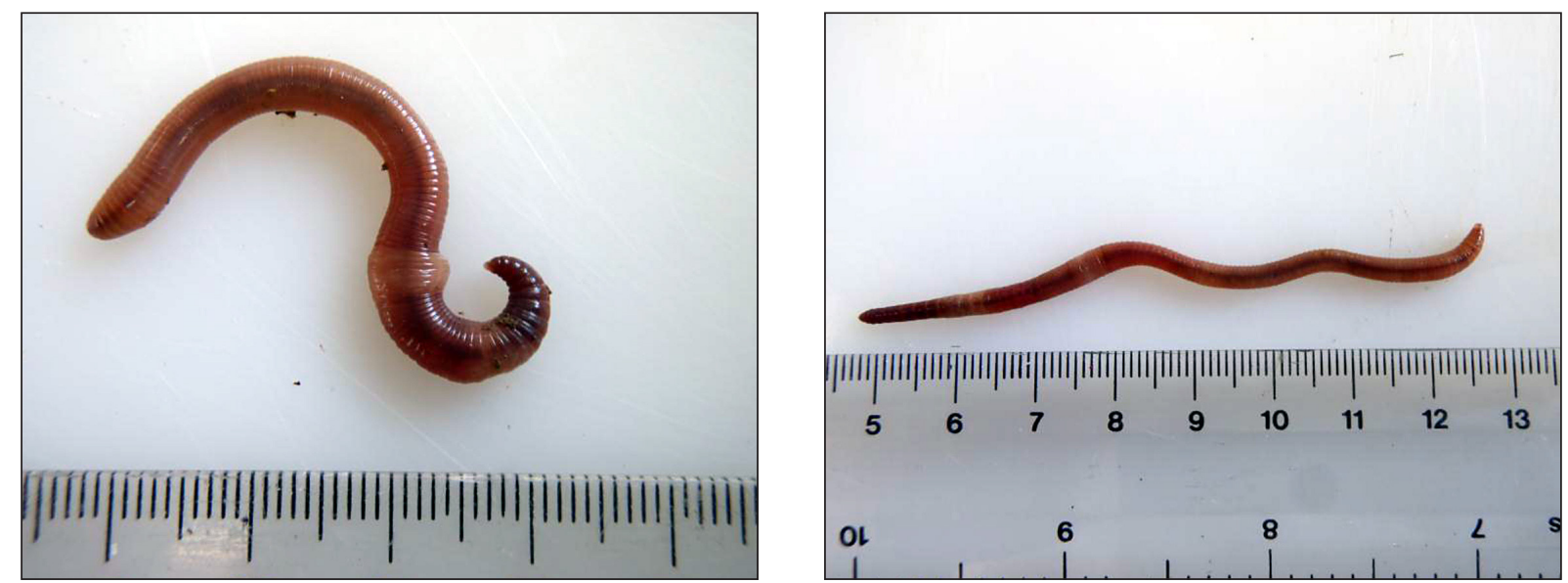

Figure 1. D. alpina earthworm; photos of the same individual - a mature specimen 
monitored for growth. Individuals $(\mathrm{n}=10)$ were kept in $0.4 \mathrm{dm}^{3}$ containers with a substrate of Kettering loam mixed with processed horse manure. These were monitored on a monthly basis over a period of 8 months.

\section{RESULTS}

Field data showed $D$. alpina to be present at all of the sampled sites. Figures $2 a$ and $2 b$ show recorded densities and biomasses, respectively over the sampling period. Of 13 earthworm species collected, D. alpina was one of only three to occur in large numbers at all sites investigated along with $A$. cernosvitoviana and $A$. carpathica. Chosen attributes of $D$. alpina from the four field sites are provided in Table 1. The density of D. alpina at Fagetum carpathicum allietosum differed significantly from that at the other sites $(\mathrm{p}<0.05)$.
The majority $(66 \%)$ of $D$. alpina were collected from soil depths of less than $0.1 \mathrm{~m}$, with a further $28 \%$ to $0.2 \mathrm{~m}$. During October and November sampling numbers obtained from handsorting at all sites were much lower in the upper levels than earlier in the year, due to the earthworms descending deeper into the soil and entering a resting state, where they protect themselves against adverse environmental conditions and do not react to extraction from deeper soil layers.

Mature D. alpina, field-collected in 2008, had a mean mass of $1.4 \mathrm{~g}(\mathrm{n}=6)$. These produced cocoons from the outset and averaged 1.83 cocoons worm $^{-1} \cdot$ month $^{-1}$ over 21 months at $15{ }^{\circ} \mathrm{C}$. Fieldcollected immature specimens, grown to maturity in the laboratory (at 0.95 to $1.4 \mathrm{~g}$ ) produced no cocoons when maintained in isolation over a two month period. However, when paired these recently matured adults (mean mass $1.32 \mathrm{~g}$ ) produced 1.65 cocoons worm $^{-1} \cdot$ month $^{-1}(9$ pairs over a period of 15 months). It is worth noting that all but two of

a)

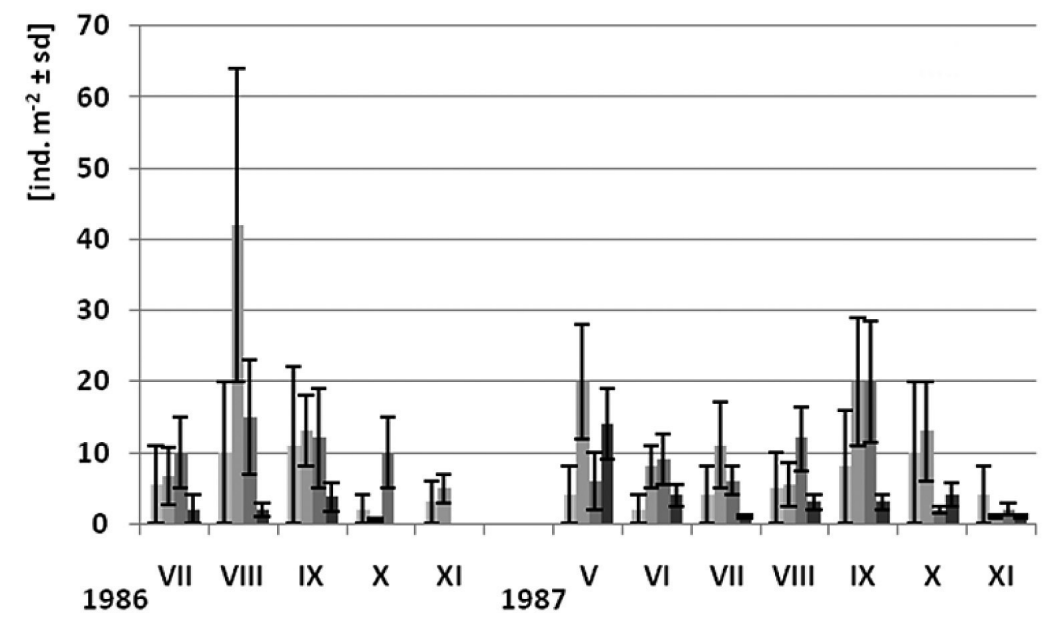

b)

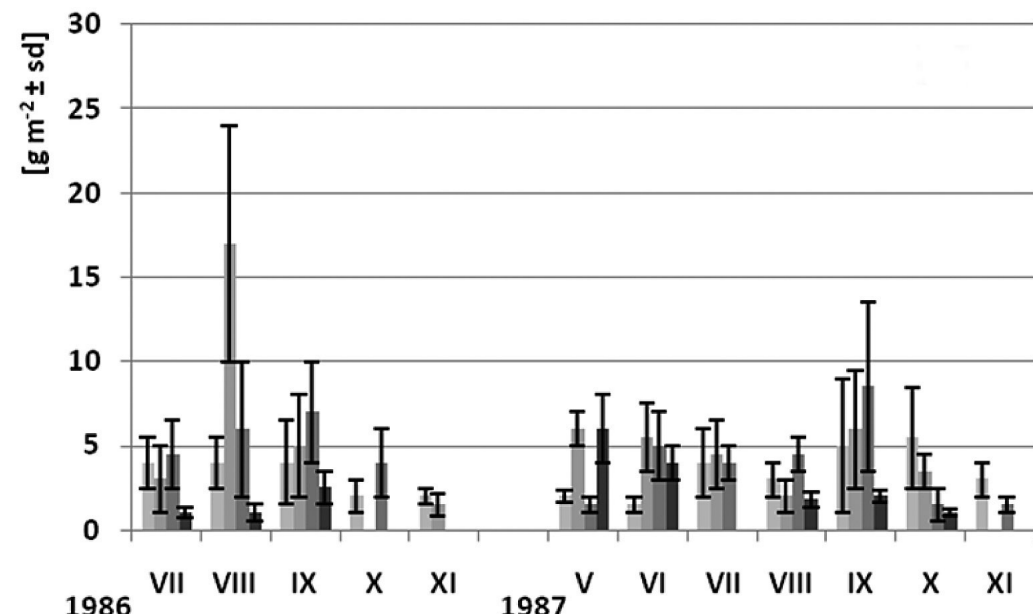

Figure 2. Dynamics of Dendrobaena alpina density (a) and biomass (b) at four differing sites of Fagetum carpathicum near Ustrzyki Górne over 2 sampling years; Bars present sites from the left to right: Fagetum carpathicum festucetosum (site I); F.c. typicum (site II); F.c. lunarietosum (site III); F.c. allietosum (site IV) 
Table 1. Selected attributes of Dendrobaena alpina from field sampling in Fagetum carpathicum near Ustrzyki Górne averaged across 2 sampling years

\begin{tabular}{|l|c|c|c|c|}
\hline \multirow{2}{*}{\multicolumn{1}{c|}{ Characteristics }} & \multicolumn{4}{c|}{ Fagetum carpathicum } \\
\cline { 2 - 5 } & festucetosum & typicum & lunarietosum & allietosum \\
\cline { 2 - 5 } & (site I) & (site II) & (site III) & (site IV) \\
\hline Mean biomass of clitellate Specimens [g] & 0.99 & 1.01 & 0.72 & 0.78 \\
\hline Mean biomass of specimens with tubercula pubertatis [g] & 0.67 & 0.82 & 0.54 & 0.71 \\
\hline Dominance [\%] & 56.0 & 36.0 & 24.8 & 11.4 \\
\hline Frequency [\%] & 43.1 & 61.1 & 37.5 & 20.4 \\
\hline Density [ind. $\cdot \mathrm{m}^{-2}$ ] & $73.7 \pm 52.0^{\text {a }}$ & $163.2 \pm 76.3^{\text {a }}$ & $233.1 \pm 125.1^{\text {a }}$ & $47.4 \pm 20.9^{\mathrm{b}}$ \\
\hline Mean biomass [g $\cdot \mathrm{m}^{-2}$ ] & $24.30 \pm 25.90$ & $66.18 \pm 30.23$ & $89.56 \pm 75.02$ & $18.94 \pm 8.95$ \\
\hline
\end{tabular}

Different letters in a row denote significant differences $(p<0.05)$.

the animals collected from the field proved to be D. alpina. The exceptions were two very small (at time of capture) Lumbricus terrestris L., but initial growth rate and lack of a "wriggling" escape response soon confirmed their identity.

D. alpina cocoons were yellow in colour and ovoid in shape $(4 \times 3 \mathrm{~mm})$ with a mean mass of 19 $\mathrm{mg}$ (range from 14 to $26 \mathrm{mg})(\mathrm{n}=178)$. At $15^{\circ} \mathrm{C}$, cocoons produced by recently matured adults during the first 2 months of production, hatched after a period calculated as 81 days with a hatching success rate of $82 \%$. Cocoons produced after this time, although showing embryo development through the translucent cocoon, mainly failed to hatch. On emergence, hatchlings had a mean mass of $18 \mathrm{mg}, 100 \%$ of cocoons produced a single wormling. Growth to maturity is shown in Figure 3. Maturity was normally reached after 7 to 8 months (at around $1.2 \mathrm{~g}$ ) with the acquisition of a fully developed clitellum, although some individuals took 11 months to reach this stage. Tubercula pubertatis were developed after a period of 5 months.

\section{DISCUSSION}

The Bieszczady Mountains in Poland are rich in earthworms species with 21 recorded from beech forest and meadows [Dumnicka and Kostecka 2000]. D. alpina abundance peaked here in July of one year followed by September the following. This compares with the results for the same species from the Apuseni Mountains of Romania in the western Carpathians, where peaks in abundance and biomass were in August [Pop and Pop 2004]. In the Bieszczady region, D. alpi$n a$ is an important earthworm species (dominance - min. 11.4 - max. 56.0\%; frequency - min. 20.8 - max. $61.1 \%$ at different sites). As POP et al. [2007] reported, D. alpina (and very similar earthworm species) has a dominant role in building up thick (10-12 cm) black organic part of soil horizons, being present in soils of different types: humico-silicatic, rendzina, acid black or podzolic brown soils, with raw or moder humus.

Data concerning the density of this earthworm in beech forests in the Bieszczady Moun-

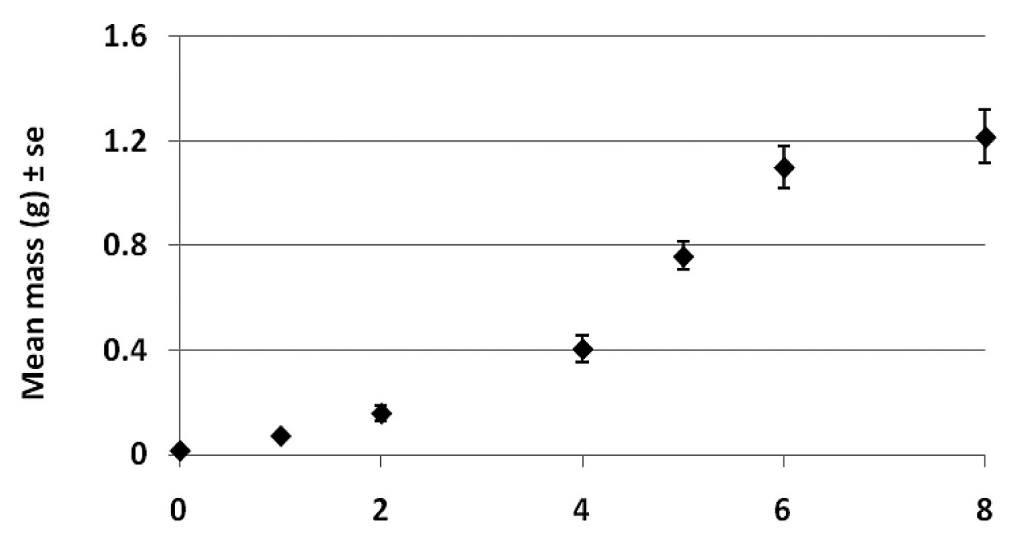

Time (months)

Figure 3. Laboratory growth of hatchling Dendrobaena alpina at $15{ }^{\circ} \mathrm{C}$ in a mixture of soil and dried, ground horse manure 
tains have shown similar values (mean 129.28 \pm 68.58 ind. $\mathrm{m}^{-2}$ ) to those recorded by POP et al. [2007] under fir trees (mean $126.99 \pm 29.76$ ind. $\left.\cdot \mathrm{m}^{-2}\right)$, but the biomass in beech forests was much higher (means of $49.75 \pm 35.02 \mathrm{~g} \cdot \mathrm{m}^{-2}$ and $9.96 \pm 2.27 \mathrm{~g} \cdot \mathrm{m}^{-2}$, respectively). This could be connected with lower $\mathrm{pH}$ and fertility, which is usually connected with the soil under the fir tree.

Field examination in October and November in the Bieszczady Mountains showed that soil layers to $20 \mathrm{~cm}$ contained very few specimens, which may imply that this species winters beneath such depths. According to Kasprzak [1986] and Plisko [1971], D. alpina is usually situated in leaf litter and beneath the bark of decaying trees. Our findings imply that this species should be considered as more than epigeic in nature.

Advancement of sustainable development and preservation of biological diversity are major tasks faced by the humanity in the $21^{\text {st }}$ century. Lumbricidae earthworms are a significant part of soil zooedaphone. They take part in key processes and changes, crucial for the life on Earth, therefore they constitute an inherent component of all categories of ecosystem services [Blouin et al. 2013].

It should be stressed that the current state of knowledge related to earthworms in Poland is unsatisfactory for both natural and anthropogenic ecosystems [Pączka et al. 2015]. This publication fulfils one of the missing gaps.

\section{CONCLUSIONS}

Monthly data on density and biomass of earthworm's species in the soil are reported by not many authors - therefore field data of D. alpina in this publication (not published before) are valuable. Laboratory findings have provided valuable information on the reproduction and growth rates of this species. Further experiments might, for example, provide improved growth rates by offering a range of culture materials with a greater organic content and more closely resembling the humic layers from which this species may be recovered in the field. Investigations as to why a large proportion of cocoons did not hatch might also be usefully looked into. This could well be an anthropogenic function of incubation conditions.

Considering the complex role of earthworms in ecosystem service provision and as "ecosystem engineers", the studies conducted could be of significance. Collection of information rel- evant to the protection of earthworms in ecosystems is also important.

\section{REFERENCES}

1. Blouin M., Hodson M.E., Delgado E.A., Baker G., Brussaard E., Butt K.R., Dai J., Dendooven L., Peres G., Tondoh J.E., Cluzeau D., Brun J.J. 2013. A review of earthworm impact on soil function and ecosystem services. European Journal of Soil Science, 64, 161-182.

2. Butt K.R., Grigoropoulou N. 2010. Basic Research Tools for Earthworm Ecology. Applied and Environmental Soil Science. 12, DOI:10.1155/2010/562816. http://www.hindawi. com/journals/aess/2010/562816.html

3. Csuzdi C., Pop A.A., Pop V.V., Wink M., Zicsi A. 2005. Revision of the Dendrobaena alpina (Rosa, 1884) species group (Oligochaeta, Lumbricidae) by morphological and molecular methods. In: V.V. Pop, A.A. Pop (Eds.), Advances in Earthworm Taxonomy II (Annelida: Oligochaeta). Cluj University Press, Cluj, 119-128.

4. Dumnicka E., Kostecka J. 2000. Review of Oligochaeta and Hirudinea of Bieszczady. Monografie Bieszczadzkie, 7, 15-28.

5. Kasprzak K. 1986. Soil Oligochaeta. III. Earthworm familly (Lumbricidae). Keys to determine invertebrates of Poland. PWN, Warszawa (in Polish).

6. Kostecka J, Skoczeń S. 1993. Earthworm (Oligochaeta, Lumbricidae) populations in four types of beech wood (Fagetum carpaticum) in the Bieszczady National Park (south-eastern Poland). Part 1. Species composition, diversity dominance, frequency and associations. Acta Zool Cracov. 36, 1-13.

7. Lowe C.N., Butt K.R. 2005. Culture techniques for soil dwelling earthworms: A review. Pedobiologia. 49, 401-413.

8. Pączka G., Mazur-Pączka A., Kostecka J. 2015. Soil fauna research in Poland: earthworms (Lumbricidae). Soil Science Annual, Vol. 66, No. 2, DOI: $10.1515 /$ ssa-2015-0018

9. Plisko J.D. 1971. Earthworms (Oligochaeta, Lumbricidae) of the Bieszczady Mountains. Fragmenta Faunistica, 17, 31-48.

10. Pop V.V., Pop A.A. 2004. A comprehensive study of the Taxonomy and ecology of the earthworm genus Octodrilus from the Carpathians. In: C.A. Edwards (Ed.), Earthworm Ecology. CRC Press, Boca Raton, 115-141.

11. Pop V.V., Pop A.A., Csuzdi C. 2007. An updated viewpoint on the earthworm communities with the Dendrobaena alpina species group (Oligochaeta, Lumbricidae) from the South-Eastern Carpathians. European Journal of Soil Biology, 43, 53-56. 